Original Research

\title{
Influence of Cognitive Stimulation Group Activity Memory Game Therapy on Elderly Cognitive Function: Quasi-Experimental
}

\section{Qolbi Nur Qoidah Yahya, Purwaningsih Purwaningsih and Makhfudli Makhfudli}

Faculty of Nursing, Universitas Airlangga, Surabaya, East Java, Indonesia

\begin{abstract}
Introduction: Older adults experience a change in their nervous system that influences cognitive function, including the abilities of orientation, registration, attention-calculation, memory and language. These changes affect the independence of the elderly when carrying out their daily activities. The purpose of this research was to analyze the effect of cognitive stimulation group activity memory game therapy on elderly cognitive function.
\end{abstract}

Methods: This study used a quasi-experimental pre-post approach with a control group design. The population in this study was the elderly who were aged $>60$ in Nursing Home Blitar, totaling 20 older patients. The data retrieval for this research was conducted between April and May 2012. The elderly in the treatment group were given flash card stimulus to practice their perceptual abilities 8 times ( 1 month). The measurement of elderly cognitive function used the Mini Mental State Examination questionnaire. The data was analyzed using the Wilcoxon Sign Rank test.

Results: The results showed that elderly cognitive function increased from 10,3 (pre test) to 14,65 (post test) with $p=0,005(p<0,05)$. This result shows that cognitive stimulation group activity memory games have a significance influence on elderly cognitive function.

Conclusion: Practical nurses can use this therapy to improve elderly cognitive function not only in Elderly Social Institutions but also in the community or through public health.

\section{ARTICLE HISTORY}

Received: December 26, 2019

Accepted: December 31, 2019

\section{KEYWORDS}

cognitive; stimulation group; activity memory; elderly

\section{CONTACT}

Qolbi Nur Qoidah Yahya

$\triangle$ qolbi.nur.qoidah2018@fkp.unair.ac.id

$\doteq$ Faculty of Nursing, Universitas Airlangga, Surabaya, Indonesia

Cite this as: Yahya, Q. N. Q., Purwaningsih, P., \& Makhfudli, M. (2019). Influence of Cognitive Stimulation Group Activity Memory Game Therapy on Elderly Cognitive Function: Quasi-Experimental. Jurnal Ners, 14(3si), 242-246 doi:http://dx.doi.org/10.20473/jn.v14i3(si).17111

\section{INTRODUCTION}

According to the Republic of Indonesia law No. 13 of 1998 concerning the welfare of the elderly, an elderly individual is someone who has reached 60 years and above. Globally, the elderly population is predicted to continue to increase as shown in the figure below. The increasing number of elderly people can be a problem. Problems that arise from the aging process cause the elderly to experience setbacks naturally in their lives, one of which is experiencing mental disorders.(Kementerian Kesehatan RI, 2013)

According to the United Nations 2015 data, the highest number of elderly people is in the Asian Continent, totaling 508 million people. The estimated number of elderly people in Indonesia reached $85 \%$ in 2015.(Kementerian Kesehatan RI, 2017) Based on the results of the 2016 Susenas, the number of elderly people in Indonesia reached 22.4 million or $8.69 \%$ of the total population. According to the 2015 BPS projection, in 2018 , the number of elderly people is estimated to reach $9.3 \%$ or 24.7 million. The elderly population in Indonesia is predicted to increase more than the elderly population globally after 2100 . The increase in the elderly population in Indonesia can cause problems related to the medical, psychological, economic and social aspects of life, making it necessary to improve the health services for the elderly. Some of these services can even begin to be given to the pre-elderly (aged 45 - 59 years).

The mental disorders commonly experienced by the elderly are depression in $63.4 \%$ and cognitive decline in $88.7 \%$. Cognitive status disorders are a decrease in the brain's cognitive abilities that include 
attention, calculation, visual-spatial, language and memory. Based on the data from the Kementrian Kesehatan RI 2013, the cognitive disorders that commonly attack the elderly are focused on language disorders (aphasia), disorientation and emotional disturbances.(Kementerian Kesehatan RI, 2013; Kusumowardani \& Puspitorini, 2014; Wreksoatmodjo \& Budi Riyanto, 2012) A decline in cognitive function in the elderly usually begins with a setback of memory such as finding things easy to forget (forgetfulness) and mild cognitive impairment (Mild Cognitive Impairment /MCI) and through to dementia as a clinical form of cognitive function disorders, the hardest of which significantly disrupts the life activities of the elderly. This includes a loss of interest in caring for themselves such as eating, bathing, recreation and socialization, which can lead to dependence by the elderly on their family. One of the impacts of the decline in cognitive status is the shifting of the elderly individual's role in social interaction activities in the community or within their families.(Kusumowardani \& Puspitorini, 2014)

Based on the preliminary data collection conducted by researchers on March 30th, 2012 at Nursing Home Blitar using the interview methods and the Mini Mental State Examination (MMSE) measuring devices, 55 elderly people were examined. The results were that $60 \%$ had decreased orientation functioning, $9 \%$ had decreased memory functioning, $12.7 \%$ had decreased memory functioning and $18.2 \%$ had decreased language functioning. The decline in cognitive function was mostly experienced by the elderly people aged 60 years and over with the education status of being elementary school graduates. The number of elderly people experiencing a decline in cognitive function has increased compared to 2011. However, the Nursing Home Blitar has not applied therapy as an effort to prevent a decline in cognitive function in the elderly.

Social interaction is an interrelated relationship between an individual and an individual, an individual with a group and a group with another group. Social interactions occur if there is communication and they can influence each other in terms of thoughts and actions.(Laelasari. Sari, S.P. dan Rejeki, 2015) In a study conducted by Kusumowardani and Puspitosari (2014), the elderly who have good social interactions totaled $15 \%$. The advantage of social interactions is that the abilities related to the memory and language skills of the elderly will always be used, so the cognitive status of the elderly is always honed. The loss of not carrying out social interactions means that the elderly individual can feel isolated. Besides that, the cognitive status of the elderly such as language skills can be decreased.(Laelasari. Sari, S.P. dan Rejeki, 2015) Group activity therapy is one form of social interaction. Sri Lestari's research results in 2010 in the elderly social institution Pare-Kediri showed that group activity therapy through reality orientation can be used to maintain the memory ability. The researcher of this study intends to develop group activity therapy in the form of memory games as an effort to improve the cognitive function of the elderly. It is called cognitive stimulation group activity memory games therapy.

\section{MATERIALS AND METHODS}

\section{Research design}

This study used a quasi experimental pre-post two group design with a control group.

\section{Population and sample}

The population was 55 older people in a nursing home and the number of samples involved in this study was 20 older people. The respondents were taken using the purposive sampling technique with both inclusion and exclusion criteria. The inclusion criteria were the elderly aged over 60 years old, suspected cognitive impairment or impaired cognitive function (MMSE score <26), living in the nursing home for at least 1 year, cooperative and they can read and write. The exclusion criteria were the elderly with physical weakness, hearing loss without aids, impaired vision without aids and severe mental disorders.

\section{Variables}

The independent variable in this study was the cognitive function of elderly. The dependent variable was cognitive stimulation through the group activity of memory game therapy.

\section{Instruments}

The study used the Mini Mental Status Examination (MMSE) questionnaire, which consists of 10 questions about orientation, 1 question about regression, 1 question about attention and calculation, 1 question about recall and 6 questions about language. The MMSE score was interpreted as normal with a score of 7 - 30, suspected cognitive function disorders with a score of $22-26$ and definite cognitive function disorders with a score of $0-21$. This study also used flash cards that contained material images, numbers and letters that adjusted to the MMSE rating format. Examples of the material on the flash cards includes calendar images, a clock picture, house drawings, numbers 1-100 and pictures of two intersecting pentagons.

\section{Research procedure}

The procedure for retrieving the data was the filling out of a questionnaire by the respondents after they had given their informed consent. This study was conducted for one month (eight sessions). Before conducting the study, the researcher divided the sample randomly into the control group and the experimental group. Each group consisted of 10 samples. The control group and the experimental group received a pre-test. The experimental group was given the cognitive stimulation group activity of memory game therapy. For the control group, daily routine activities were provided in the elderly social institution. The post-tests for both two groups were given 1 day after the last session. 
The cognitive stimulation group activity memory game therapy was given twice a week (Tuesday and Thursday) for 1 month. The meeting took place at 10:00 - 11:00 o'clock. The researcher took 10 minutes to prepare the place and tools, 40 minutes for the therapy itself and 10 minutes for tidying up the place and the tools used. The activities were carried out in accordance with the guidelines for Group Activity Therapy: Cognitive Stimulation, which consist of 5 stages, namely preparation, orientation, contract time, work and termination. The implementation of this therapy involved the researcher (leader) and the daily staff of the institution ( 2 people) as co-leader and facilitator respectively. The leader played the role of leading the course of activities while the co-leader played a role in observing the activities. The facilitator played a role in facilitating the respondents and preparing the infrastructure. The technical implementation of this therapy began with positioning the respondent to sit around the leader. The leader began the therapy by saying hello and asking how the respondent was, explaining the intent and purpose of each meeting and making a time contract. In the work stage, the leader asked the respondent to take one flash card prepared in front of each respondent and they then asked the respondent to tell them the contents of the flash card. This activity continued until all the cards in front of the respondent were used up. In the termination stage, the leader asked for help from the co-leader to evaluate and read out the values obtained where the respondent was able to explain the contents of the flash card correctly. Before the activity was closed, the leader made a time contract for the next meeting.

\section{Analysis of the research}

The collected data was analyzed using the Wilcoxon Sign Rank test.

\section{RESULTS}

The number of elderly in the nursing home was 55 people. Most (60\%) of the elderly in Blitar Nursing Home are suspected of having impaired cognitive function. For the elderly who live in the nursing home, $85 \%$ were a widow / widower whose partner had died and $85 \%$ of them had been at a/the nursing home for 1 - 5 years. The pre-test results on the 20 respondents showed that $70 \%$ were suspected of having cognitive impairment and 30\% had impaired cognitive function. The pre-test results in the control group and the experimental group showed that $75 \%$ were suspected of impaired cognitive function. In the treatment group, $80 \%$ of the respondents experienced a disruption in orientation, $10 \%$ had a disorder of registration, $20 \%$ had an attentioncalculation disorder, $50 \%$ had a disturbance in remembering and $30 \%$ had a disorder in relation to language. The post-test results in the treatment group showed an increase in the MMSE scores for $90 \%$ and as many as $70 \%$ ( 7 people) were stated as having normal cognitive function. In the control group, the post-test results showed that $70 \%$ had impaired cognitive function.

Table 1 is the demographic data of the respondents in the Blitar nursing home. In the elderly with an age of 60 years, the nervous system starts to deteriorate which results in their cognitive function decreasing. The respondents involved in this study had an age range of 60 - 90 years old. The level of education is critical when related to the cognitive function of the elderly. The elderly who had a lower education level made up the majority (Sinthania, 2015) The elderly had all lived in the or other nursing

Table 1. Respondent's demographic data in the Blitar Nursing Home in May 2012

\begin{tabular}{lcc}
\hline \multicolumn{1}{c}{ Demographic Data } & n & \% \\
\hline Ages in year & & \\
$60-74$ years & 14 & 70 \\
$75-90$ years & 6 & 30 \\
Level of education & & \\
$\quad$ Primary school & 20 & 100 \\
$\quad$ Secondary school & - & - \\
Stay in nursing home & & \\
1 - 5 years & 15 & 75 \\
6 - 10 years & 5 & 25 \\
Marriage status & & \\
Married & - & - \\
Not Married & 2 & 10 \\
Divorced & - & - \\
Widowed & 18 & 90 \\
\hline
\end{tabular}

Table 2. Respondent's cognitive function in the Blitar Nursing Home in May 2012

\begin{tabular}{lcc}
\hline \multicolumn{1}{c}{ Cognitive Function } & $\mathbf{n}$ & $\mathbf{\%}$ \\
\hline $\begin{array}{l}\text { Normal } \\
\begin{array}{l}\text { Suspected cognitive } \\
\text { impairment }\end{array}\end{array}$ & - & - \\
Cognitive impairment & 6 & 70 \\
\hline
\end{tabular}

Table 3. Respondent's cognitive function pre- and post-experiment in the Blitar Nursing Home in May 2012

\begin{tabular}{|c|c|c|c|c|}
\hline \multirow[t]{2}{*}{ Cognitive Function } & \multicolumn{2}{|c|}{ Pre Test } & \multicolumn{2}{|c|}{ Post Test } \\
\hline & n & $\%$ & $\mathbf{n}$ & $\%$ \\
\hline \multicolumn{5}{|l|}{ Control group } \\
\hline Normal & - & - & - & - \\
\hline $\begin{array}{l}\text { Suspected cognitive } \\
\text { impairment }\end{array}$ & 8 & 80 & 6 & 60 \\
\hline $\begin{array}{l}\text { Cognitive } \\
\text { impairment }\end{array}$ & 2 & 20 & 4 & 40 \\
\hline \multicolumn{5}{|l|}{ Experimental group } \\
\hline Normal & & & 7 & 70 \\
\hline $\begin{array}{l}\text { Suspected cognitive } \\
\text { impairment }\end{array}$ & 8 & 80 & 2 & 20 \\
\hline $\begin{array}{l}\text { Cognitive } \\
\text { impairment }\end{array}$ & 2 & 20 & 1 & 10 \\
\hline
\end{tabular}

Table 4. Comparison of the cognitive function impairment of the experimental group pre-posttest

\begin{tabular}{lcc}
\hline $\begin{array}{c}\text { Cognitive Function } \\
\text { Impairment }\end{array}$ & Pre (\%) & Post (\%) \\
\hline Orientation & 80 & 80 \\
Registration & 10 & - \\
Attention-Calculation & 20 & - \\
Memory & 50 & - \\
Language & 30 & 30 \\
\hline
\end{tabular}


homes for a long time. The respondents involved in the study had lived in nursing homes for between 1 10 years. Marriage status also affects cognitive function. Most of the respondents were widowed.

Based on Table 2, it can be seen that most (70\%) of the cognitive functions of the respondents had an MMSE score between 22 - 26. Most of the respondents began to see a change in their cognitive function.

Table 3 shows the changes in the cognitive function of the respondents pre- and postexperiment. After following along with the cognitive stimulation activity of group memory games, as many as 9 people $(90 \%)$ in the treatment group experienced an increase in cognitive function and as many as 7 people $(70 \%)$ were stated to have normal cognitive function. In the control group, as many as 6 people $(60 \%)$ were still suspected of having impaired cognitive function and as many as 4 people $(40 \%)$ had impaired cognitive function.

Based on Table 4, we are able to describe the differences in the cognitive function of the elderly in the experimental group pre- and post-therapy. In the results of the pre-test, there were 5 types of cognitive function disorder in the elderly and most (80\%) experienced orientation disorders. In the post-test results, there were only 2 types of cognitive function disorders that occurred in the elderly, namely orientation and language. Orientation disorders are still mostly experienced by the elderly, for as many as 8 people (80\%).

\section{DISCUSSION}

The results of the analysis in this study were based on the value of significance indicating that cognitive stimulation group activity memory games have a significance influence on the cognitive function of the elderly. Changes in cognitive function begin to be experienced by someone aged over 60 years old. The changes in a person's cognitive function are influenced by age and education level. Increasing age will change the brain, which triggers changes in a person's thinking process. The higher the level of education of a person, the more they tend to have better cognitive function despite being of the same age. Impaired cognitive function that occurs in the elderly is closely related to brain function disorders in terms of orientation, attention, concentration, memory, language and intelligence. Impaired cognitive function is a disorder similar to dementia which is shown by the presence of numerical disorders, semantic memory (words) and problem solving. Impaired cognitive function that does not get immediate treatment for a long period of time will increase the likelihood of dementia.

Decreased cognitive status in the elderly is caused by several factors. The impact of the decline in the cognitive status of the elderly is the shift in the role of the elderly in their social interaction activities in both the community and in their family. Someone who has decreased cognitive status will experience changes in the form of thinking, somatic sensation and activity and they become less productive in terms of developing the mind, talking and socializing (Kusumowardani \& Puspitorini, 2014). Cognitive damage occurs in the area of the cerebral cortex and limbic system. The cerebral cortex as a center for information from the brain, as it accepts, opposes and processes information which then becomes a reference for making decisions. Memory (recall), visual-spatial functions and the ability to calculate and construct data and complexes becomes an understanding of coordination through the functions of the cerebral cortex. Damage to the cortex causes damage to language. The function of the cortex regulates intelligence which consists of perception, thinking, understanding and hearing. The cerebral cortex is used for developing and interpreting data, making observations, solving problems and making conclusions. The limbic system regulates logic and memory and it is the basic driver for eating and sex aggression. Intelligence, memory, ability to learn and a normal personality do not change in the elderly. In general, nerve cells cannot be repaired if there is damage. Brain cell damage will result in permanent damage to some or all mental functions. (Stuart, G.W., \& Sundeen, 2000) The results of this research were analyzed using the Wilcoxon Sign Rank test for the pre-post tests on the experimental group, showing a significance value of $p=0.005(p<0.05)$. This means that cognitive stimulation group activity memory games have a significant influence on the cognitive function of the elderly. In the experimental group, there were differences in the cognitive function status of the respondents before and after cognitive stimulation in the form of the group activity of the memory games therapy. As many as 70\% showed MMSE scores in the normal range between 27 - 30, while $20 \%$ were still suspected of impaired cognitive function and $10 \%$ were still experiencing impaired cognitive function. In the post-test results of the experimental group, it was explained that the respondents who were still experiencing interference in orientation amounted to $80 \%$ and that $20 \%$ still experienced interference in language.

Cognitive stimulation activity in the form of group memory games is a type of therapy that uses techniques to strengthen the stimuli by involving the participation or interaction of the group members guided by a nurse. During therapy, there will be interactions and dynamics that depend, need and can be used as a place for the group members to practice adaptive behavior and to practice perceiving a stimulus. The existence of other group members is able to stimulate its members to provide opinions and responses and to create a conducive atmosphere to train their members to socialize and communicate (Keliat dan Akemat, 2005). Regular and pleasant stimuli in the form of group activities will facilitate the work of the brain in the acceptance process (apprehending phase) acquisition, (acquisition phase), storage (storage phase) and re-disclosure (retrieval phase) (Simamora, 2008). A person with cognitive function disorders must be given activities 
in a structured manner and they need to be involved directly in each scheduled activity. The respondents who experience severe cognitive function impairment (MMSE score <21) can be given cognitive stimulation therapy activity group memory games if there is an increase in the intensity of their activities. Cognitive stimulation activity group memory games are not new as an intervention for patients who experience psychiatric disorders. However, this therapy has never been done to stimulate cognitive function in the elderly who experience decreased cognitive function. There is no previous research that proves that cognitive stimulation therapy in the form of memory activities in groups has a significant influence on elderly cognitive function. The results of this study are expected to be used as therapeutic modalities by the nurses in elderly social institutions or in public health care to stimulate the cognitive function abilities of the elderly who begin experiencing intellectual disability.

\section{CONCLUSION}

There is an influence from the cognitive stimulation group activity memory game therapy on the elderly individual's cognitive function. This therapy can be used to train the cognitive functions of the elderly that have begun to decline, both those in social care institutions and in public health services.

\section{REFERENCES}

Keliat dan Akemat. (2005). Keperawatan Jiwa Terapi Aktivitas Kelompok. Jakarta: EGC.
Kementerian Kesehatan RI. (2013). Buletin jendela data dan informasi kesehatan: gambaran kesehatan lanjut usia di Indonesia. Retrieved February 25, 2012, from www.depkes.go.id/download.php?file=download /pusdatin/buletin/buletin-lansia.pdf

Kementerian Kesehatan RI. (2017). United Nations 2015: World Population Aging, New York. Jakarta: Kementrian Kesehatan RI.

Kusumowardani, A., \& Puspitorini, A. (2014). Hubungan Antara Tingkat Depresi Lansia Dengan Interkasi Sosial Lansia di Desa Sobokerto Kecamatan Ngemplak Boyolali. Jurnal Ilmu Kesehatan.

Laelasari. Sari, S.P. dan Rejeki, Y. F. (2015). Faktorfaktor Yang Berhubungan dengan Aktivitas Fisik Lansia Di Posbindu Anggrek Wilayah Kerja Puskesmas Sindangjaya Kota Bandung. Jurnal Keperawatan.

Simamora, R. . (2008). Buku Pendidikan dalam Keperawatan. Jakarta: EGC.

Sinthania, D. (2015). Studi Fenomena: Pengalaman Interaksi Sosial Lansia dengan Sesama Lansia dan Pengasuh di Panti Sosial Tresna Werdha "Sabai Nan Aluih" Sicincin Kabupaten Padang Pariaman. Jurnal Kesehatan STIKes Prima Nusantara Bukittinggi, 6(2).

Stuart, G.W., \& Sundeen, S. . (2000). Principles and Practice of Psychiatric Nursing (7th ed.). St. Louis: Mosby Year Book.

Wreksoatmodjo \& Budi Riyanto. (2012). Hubungan Social Engangement dengan Fungsi Kognitif (2nd ed.). Jakarta: CDK-190 39. 